\title{
Tree Growth Response Along Seismic Lines in Alberta
}

\author{
by
}

\author{
I.E. Bella ${ }^{1}$
}

\begin{abstract}
Stem growth data from breast height were collected from about 2000 trees on 192 sample transects (plots) located adjacent to seismic lines. Sampled stands represented the most important forest cover types between 10 and 100 years of age over a range of site conditions in the foothills of western Alberta from Rocky Mountain House to Grande Prairie. Line clearing stimulated breast height radial increment fairly consistently in the $20 \%$ range of lodgepole pine (Pinus contorta Dougl. var. latifolia Engelm.), white spruce (Picea glauca (Moench) Voss), and black spruce (Picea mariana (Mill.) B.S.P.) trees. This improvement expressed in terms of stand growth, however, fell far short of that required to make up for the loss of wood production over these lines if the cut trees are not utilized. The lack of significant stimulation from line clearing in aspen (Populus tremuloides Michx.) stands indicates a complete loss of production due to the lines.
\end{abstract}

\section{Résumé}

Des données sur la croissance de la tige à hauteur de poitrine ont été recueillies dans 192 transects (placettes) localisés le long de ligne seismique. Les quelque 2000 arbres de 10 à 100 ans ainsi échantilIonnés, dans les piedmonts de l'ouest de l'Alberta, de Rocky Mountain House à Grande Prairie, représentaient les types les plus importants de couvert forestier, et les conditions des diverses stations variaient. Dans le cas du pin tordu (Pinus contorta Dougl. var. Iatifolia Engelm.), de l'épinette blanche (Picea glauca (Moench) Voss) et de l'épinette noire (Picea mariana (Mill.) B.S.P.), le défrichement des lignes a stimulé de façon assez constante l'accroissement radial à hauteur de poitrine dans une proportion d'environ $20 \%$. Du point de vue de la croissance des peuplements, cette amélioration a été loin d'être suffisante pour suppléer au manque de bois produit le long de ces lignes si les arbres abattus ne sont pas utilisés. Comme le défrichement n'a pas causé de stimulation significative chez le peuplier faux-tremble (Populus tremuloides Michx.), les lignes défrichées constituent une perte complète de production.

\section{Introduction}

Oil, gas and to a lesser extent, coal exploration and development activities result in forests being cut over considerable areas; seismic lines constitute the largest portion, about $70 \%$ of such disturbances. ${ }^{2}$ Additional forest land losses occur from roads, powerline and pipeline right-ofways. In the 1970's, the petroleum industry rivaled the forest industry in the amount of forest cleared in Alberta (Dancik et al. 1979). According to that report, 234000 ha had been disturbed between 1956 and 1976 by exploration lines alone, compared with 255692 ha that were harvested for timber. In 1976, the figures were 14483 ha for the petroleum industry and 19068 ha for the forest industry. To put these figures in perspective, it should be noted that all nonrenewable resource-related disturbances amounted to under $1 \%$ of the

'Northern Foresty Centre, Canadian Forestry Service, 5320 - 122 Street, Edmonton, Alberta T6H $3 \mathrm{~S} 5$

${ }^{2}$ Hardy Associates (1978) Ltd. 1981. Forest depletion by energy development in the green area of Alberta. Unpublished report.

total forest area.

Although cleared lines do benefit forest management and other uses through improved access, they have two major impacts of interest to the forest land manager: (1) the immediate loss, unless salvaged, of merchantable timber on these cleared areas, and (2) their effect on the growth of stands adjacent to the openings.

The immediate loss of timber can be estimated by standard forest industry inventory techniques, and was not the object of this study. The assessment of possible effects on growth is a more difficult problem. Casual observations of trees on stand edges and studies along logging trails and roads in other forest cover types (Landbeck 1965; Pfister 1969 ) suggested greater diameter and height growth of trees adjacent to openings compared with trees located within the stands. 
The purpose of this study was to assess tree growth along cut lines for the major tree species and a range of stand conditions, and to estimate change in future yields for the entire forest area involved (i.e., lines cleared plus adjacent stocked area).

\section{Sampling Area and Methods}

The most valuable timber, mainly coniferous, is located in the western part of Alberta. This is also the prime area for oil and gas exploration. Sampling was concentrated in the Edson and Whitecourt forests, and to a lesser extent in the RockyClearwater, Grande Prairie, and Slave Lake Forests (Figure 1). Emphasis was on sampling lodgepole pine (Pinus contorta Dougl. var. latifolia Engelm.) and white spruce (Picea glauca (Moench) Voss) cover types, but some black spruce (Picea mariana (Mill.) B.S.P.) and hardwood (e.g., aspen, Populus tremuloides Michx.) types were also included. In the summer of 1981,192 sample transacts were established in stand types between 20 and 100 years old ( 10 years and over in aspen) to represent the range of site conditions present in the area (Table 1).

Only stands with cut lines established at least 10 years earlier were sampled. First, total mean height $(\mathrm{H})$ and age at stump height of three or four dominant and codominant trees were determined. In any one stand, up to three sample transects (plots) were established using a relascope-line sampling procedure (Figure 2) where the following information was recorded:

a. length of transect, $\mathrm{L}=\mathrm{H}(\mathrm{m})$;

b. aspect and slope;

c. diameter at breast height $(\mathrm{dbh})(\mathrm{cm})$ of all "in" trees by species and distance from edge $(\mathrm{m})$;

d. ten (10) sample trees ( 8 dominants and codominants, 2 intermediates) were selected in pure stands where at least $80 \%$ of basal area (BA) was in one species; in mixed two-species stands, 14 trees were selected in proportion to the species mix (10 dominants and codominants and 4 intermediates). Sample trees were marked to identify the side toward the cut line and felled. A stem disc was obtained from each tree sampled at breast height. In the laboratory, one surface of each disc was sanded and four radii marked:

$\mathrm{R} 1$ - radius towards line opening;

$\mathrm{R} 2$ - radius away from line opening;

$\mathrm{R} 3$ and $\mathrm{R} 4$ - two mean radii based on the section's diameter under bark.

The following points were marked on each radius: (1) time of line clearing, (2) 5 years before clearing, (3) 2 years

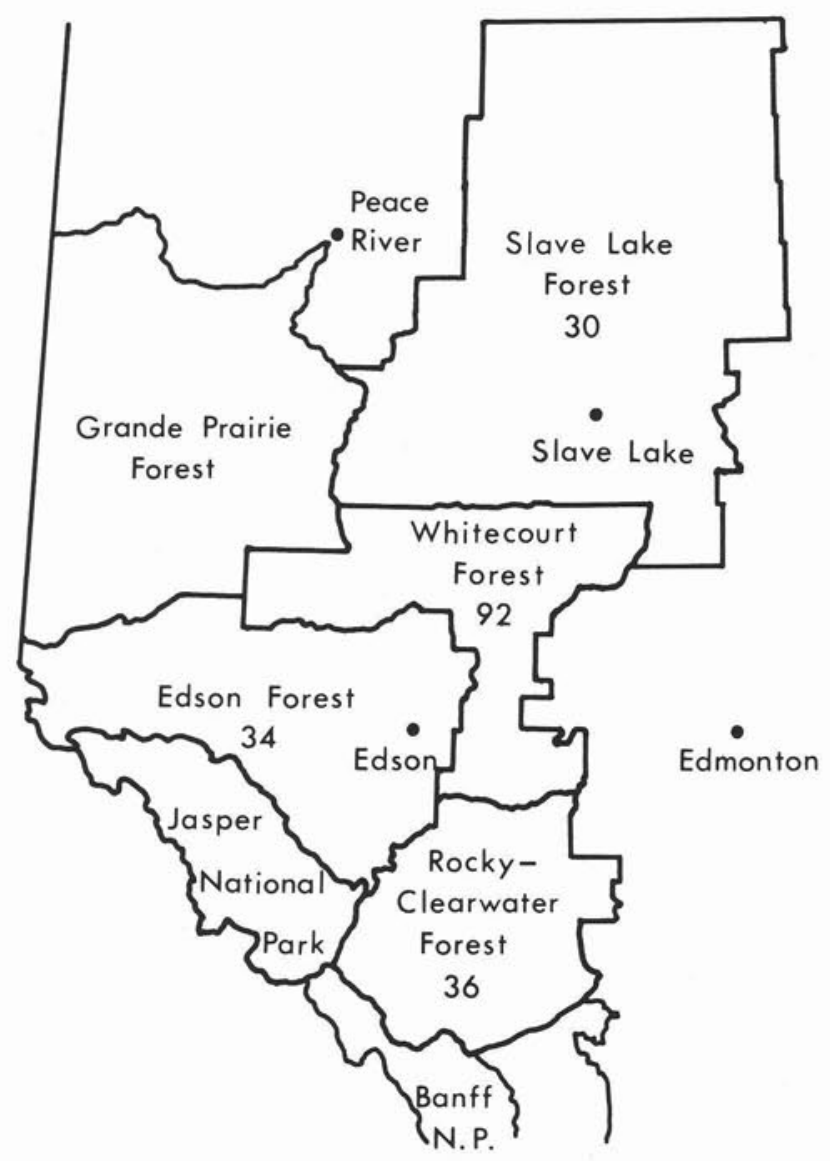

Figure 1. Provincial forests in which sample plots were located.

after, then every 5 years after clearing until the cambrium of the current year's annual ring was reached. Measurements were done on an ADDO-X ring measuring machine.

\section{Analysis}

The analysis consisted of three phases. The first series of analyses was conducted to identify and quantify (screen) the effect of all the measured independent variables that influence tree growth along seismic lines in different periods before and after line clearing. Of greatest interest was determining the importance of the tree variable "distance from stand edge" in explaining variation in radial growth after line clearing. Nonsignificance of the distance variable would sug-

Table 1. Number of sample transects by species and age.

\begin{tabular}{|c|c|c|c|c|c|c|c|c|c|c|c|c|c|c|}
\hline \multirow[b]{2}{*}{ Species 1} & \multicolumn{13}{|c|}{ Age class } & \multirow[b]{2}{*}{ Total } \\
\hline & $0-10$ & $11-20$ & $21-30$ & $31-40$ & $41-50$ & $51-60$ & $61-70$ & $71-80$ & $81-90$ & $91-100$ & $101-110$ & $111-120$ & $121+$ & \\
\hline $1 \mathrm{P}$ & & 5 & 30 & 16 & 27 & 2 & 6 & 13 & 2 & 1 & & & 1. & 103 \\
\hline wS & & & 2 & 5 & 15 & 3 & & & & & & & & 25 \\
\hline bS & & & & 2 & 12 & 2 & 2 & 1 & 2 & 3 & & & & 24 \\
\hline$t A$ & 2 & 3 & 18 & 15 & 2 & & & & & & & & & 40 \\
\hline Total & 2 & 8 & 50 & 38 & 56 & 7 & 8 & 14 & 4 & 4 & & & 1 & 192 \\
\hline
\end{tabular}

$11 \mathrm{P}=$ lodgepole pine

$w S=$ white spruce

WS $=$ white spruce
bS $=$ black spruce

$\mathrm{bS}=$ black spr
$\mathrm{t} A=$ trembling 
1, 2 .......10 Trees sampled

$1_{1}, 1_{2}, 1_{3}, \ldots .$. Tree distance from cut line

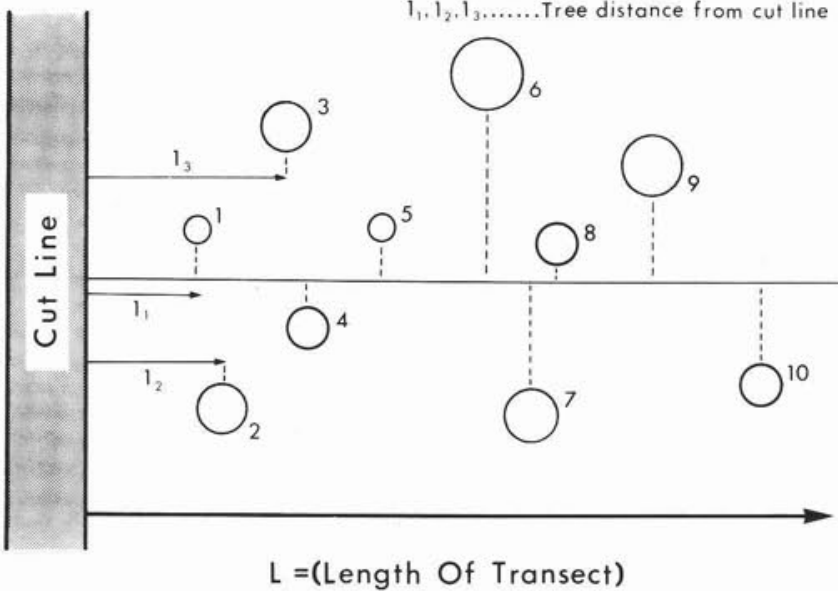

Figure 2. Sampling procedure.

gest lack of influence on tree growth. The second series of analyses was performed to derive regression functions for estimating tree diameter growth at breast height adjacent to seismic lines under the range of conditions sampled. The final phase was to convert those tree growth relationships into stand growth.

The analyses of radial increment for the four species groups - lodgepole pine, white spruce, black spruce, and trembling aspen were conducted by multiple linear regression techniques using backward elimination that included tree and stand characteristics as independent variables. were:

The dependent variables, all radial increments in $\mathrm{cm}$,

INC -5

$\mathrm{INC}+2$

$\mathrm{INC}+3 \bullet 5$

for the 5 years preceding line clearing

for the first 2 years after line clearing

between 3-5 years (i.e., 3-year period after clearing

INC $+6 \bullet 10$ for the 5 -year period $6-10$ years after line clearing

INC $+11 \bullet 15$ for the 5 -year period $11-15$ years after line clearing

INC $+16 \bullet 20$ for the 5 -year period $16-20$ years after line clearing

RINC
Independent variables:

LR distance ratio: a fraction of tree distance to length of transect

LR $^{2} \quad$ LR squared

AGEAC tree age at breast height, at the time of line clearings

$A D$

RAC quadratic mean stand diameter at the time of sampling $(\mathrm{cm})$

average stem radius at bh at the time of sampling $(\mathrm{cm})$

$\mathrm{RAC}^{2} \quad$ RAC squared

$\mathrm{H} / \mathrm{A} \quad$ mean dominant height over age at stump

BA stand basal area $\mathrm{m}^{2} / \mathrm{ha}$ at the time of samRD $\quad \mathrm{BA} / \sqrt{ } \mathrm{AD}$, a stand density index (after CurYSC years since line clearing

A preliminary analysis of the data showed no significant differences in radial increment between stem radius towards opening and radius away from opening in the growth periods following line clearing. Therefore, in the ensuing analysis the average of the four stem radii per section was used.

\section{Results and Discussion}

\section{Screening for Variables Affecting Periodic Increment}

These analyses found that prior to line clearing, six significant $(P<0.01)$ variables explained as much as $56 \%$ variation in radial increment of lodgepole pine, and about $47 \%$ in aspen.

In the 2-year period after line clearing in pine, the number of significant variables dropped to three and the amount variation explained to $36 \%$. This suggests that clearing temporarily increased the amount of random variation in increment. In the subsequent periods, the amount of variations explained increased and tree distance from edge (LR) emerged as the second most important variable after age (AGEAC).

Table 2 shows the amount of variation in increment explained by AGEAC and LR in pine. These regressions describe tree increment from stand edge to halfway $(L R<0.5)$ along the transect, as related analyses indicated that release effect extends only to half the total tree height into the stand. Trends plotted from these regressions are shown in Figure 3. Overall, the increase in radial increment at breast height varied from $24 \%$ for the $15-20$-year period to $41 \%$ for the $5-10$ year period after line clearing. Thus, highest response occurred during the first 10 years after clearing.

Table 2. Breast height radial increment regression statistics for lodgepole pine.

\begin{tabular}{|c|c|c|c|c|c|c|c|c|c|}
\hline \multirow[b]{2}{*}{$\begin{array}{l}\text { Dependent } \\
\text { variable }\end{array}$} & \multirow[b]{2}{*}{$\begin{array}{c}\text { Mean } \\
\text { AGEAC }\end{array}$} & \multicolumn{3}{|c|}{ Regression coefficeints } & \multirow[b]{2}{*}{$\begin{array}{c}\text { Number } \\
\text { of } \\
\text { observ. }\end{array}$} & \multirow[b]{2}{*}{$\mathbf{R}^{2}$ or $\mathbf{r}^{2}$} & \multicolumn{2}{|c|}{ Mean increment } & \multirow[b]{2}{*}{ Response } \\
\hline & & $\begin{array}{l}x_{1}=L R \\
a\end{array}$ & $\mathbf{b}_{1}^{\mathbf{X}_{2}}$ & $=\underset{\mathbf{b}_{2}}{\mathbf{A G E A C}}$ & & & $\begin{array}{c}\text { Response } \\
\text { half } \\
\text { mm }\end{array}$ & $\begin{array}{l}\text { No resp. } \\
\text { half } \\
\text { ear }\end{array}$ & \\
\hline $\mathrm{INC}+3.5$ & $\begin{array}{l}26.8 \\
26.8\end{array}$ & $\begin{array}{l}2.09 \\
1.95\end{array}$ & $\begin{array}{c}-0.702 \\
\mathrm{NA}^{1}\end{array}$ & $\begin{array}{l}-0.023 \\
-0.022\end{array}$ & $\begin{array}{l}577 \\
577\end{array}$ & $\begin{array}{l}0.388 \\
0.369\end{array}$ & $\begin{array}{l}1.37 \\
1.37\end{array}$ & $\begin{array}{l}1.06 \\
1.06\end{array}$ & $\begin{array}{l}28 \\
28\end{array}$ \\
\hline INC $+6 \cdot 10$ & $\begin{array}{l}26.3 \\
26.3\end{array}$ & $\begin{array}{l}1.91 \\
1.72\end{array}$ & $\begin{array}{c}-1.00 \\
\text { NA }\end{array}$ & $\begin{array}{l}-0.017 \\
-0.016\end{array}$ & $\begin{array}{l}549 \\
549\end{array}$ & $\begin{array}{l}0.351 \\
0.293\end{array}$ & $\begin{array}{l}1.28 \\
1.28\end{array}$ & $\begin{array}{l}0.91 \\
0.91\end{array}$ & $\begin{array}{l}41 \\
41\end{array}$ \\
\hline INC+11.15 & $\begin{array}{l}28.4 \\
28.4\end{array}$ & $\begin{array}{l}1.59 \\
1.44\end{array}$ & $\begin{array}{c}-0.72 \\
\text { NA }\end{array}$ & $\begin{array}{l}-0.014 \\
-0.014\end{array}$ & $\begin{array}{l}309 \\
309\end{array}$ & $\begin{array}{l}0.240 \\
0.205\end{array}$ & $\begin{array}{l}1.04 \\
1.04\end{array}$ & $\begin{array}{l}0.78 \\
0.78\end{array}$ & $\begin{array}{l}33 \\
33\end{array}$ \\
\hline INC+16.20 & $\begin{array}{l}33.0 \\
33.0\end{array}$ & $\begin{array}{l}1.20 \\
1.08\end{array}$ & $\begin{array}{c}-0.61 \\
\text { NA }\end{array}$ & $\begin{array}{l}-0.0063 \\
-0.0060\end{array}$ & $\begin{array}{l}187 \\
187\end{array}$ & $\begin{array}{l}0.134 \\
0.089\end{array}$ & $\begin{array}{l}0.88 \\
0.88\end{array}$ & $\begin{array}{l}0.71 \\
0.71\end{array}$ & $\begin{array}{l}24 \\
24\end{array}$ \\
\hline
\end{tabular}

1Not applicable. 


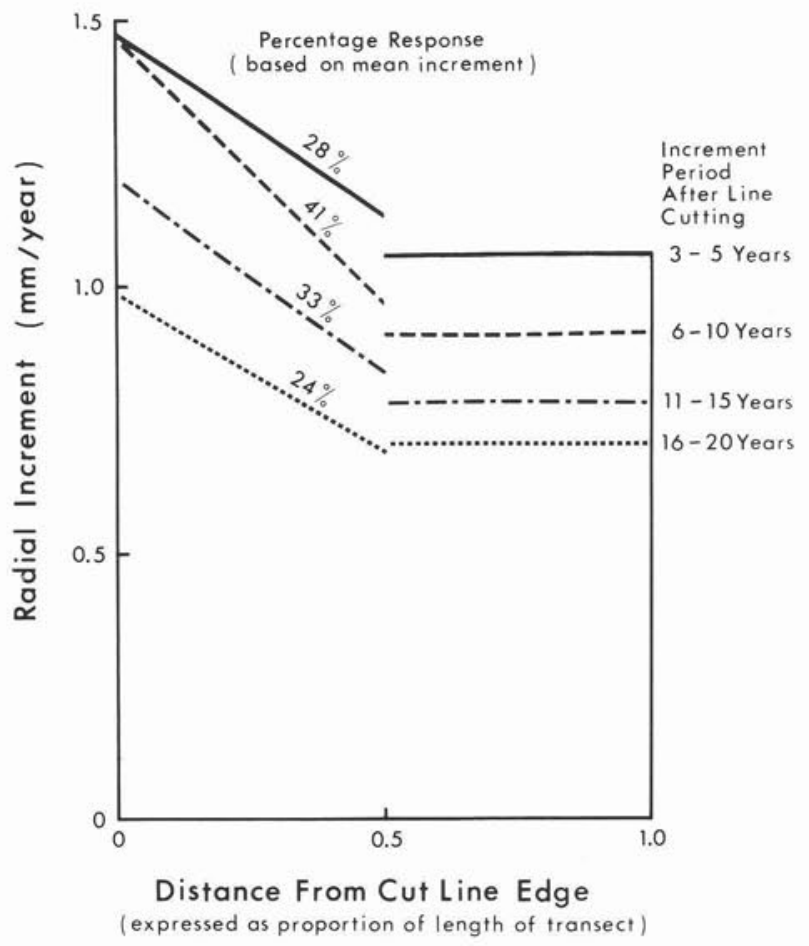

Figure 3. Radial increment at breast height of lodgepole pine trees following line clearing.

White spruce showed a consistent and almost immediate (within 5 years) response to line clearing in the 15 to $20 \%$ range. Black spruce showed a significant increment response of nearly $10 \%$ within the first 5 years, which increased to $20 \%$ in subsequent growth periods. Tree distance from stand edge (LR) was generally among the two or three most important variables for both spruces.

For aspen, the amount of variation explained in radial increment declined from $47 \%$ before clearing to around $10 \%$ following clearing, with the distance variable showing marginal significance.

\section{Regressions to Estimate Diameter Growth}

This series of analyses was conducted on the entire set of post-line-clearing data from trees in the responding half of the transect to derive multiple regressions for estimating diameter growth under different conditions. Years since clearing (YSC) specified the actual period considered. The best regression for lodgepole pine had seven significant $(P<0.01)$ independent variables and explained $45 \%$ of the variation in radial increment. The behavior of all the variables was found consistent with the preceding regression analyses results and seems to agree with current knowledge about tree and stand growth. For example, radial increment decreased with distance from edge (LR), stand $B A$, age at the time of clearing (AGEAC), and number of years since clearing (YSC); and increased with $\mathrm{H} / \mathrm{A}$, and breast height stem radius at disturbance (RAC). In these regressions, distance from edge was among the three most important variables (with $\mathrm{H} / \mathrm{A}$ and $\mathrm{BA}$ ) that explained $41 \%$ of the variation in radial increment. The best regressions for the three species (all independent variables significant at $P<0.01$ and in descending order of importance) were: for lodgepole pine

$\mathrm{RINC}=$

$$
\begin{aligned}
& 0.88+2.89 \mathrm{H} / \mathrm{A}-0.74 \mathrm{LR}-0.025 \mathrm{BA} \\
& -0.015 \mathrm{YSC}+0.048 \mathrm{RD}-0.0063 \mathrm{AGEAC}+0.032 \mathrm{RAC} \\
& \mathrm{N}=2107 \quad \mathrm{R}^{2}=0.449 \quad \mathrm{SE}=0.521 \mathrm{~mm}
\end{aligned}
$$

for white spruce

$\mathrm{RINC}=$

$$
\begin{aligned}
& 2.19-0.052 \text { AGEAC }-1.05 \mathrm{LR}+0.67 \mathrm{RAC} \\
& -0.046 \mathrm{RAC}^{2}-0.091 \mathrm{AD} \\
& \mathrm{N}=658 \quad \mathrm{R}^{2}=0.34 \quad \mathrm{SE}=0.524 \mathrm{~mm}
\end{aligned}
$$

for black spruce

$\mathrm{RINC}=$

$$
\begin{aligned}
& 0.62+2.62 \mathrm{H} / \mathrm{A}-0.24 \mathrm{LR}+0.014 \mathrm{YSC} \\
& -0.0047 \text { AGEAC }-0.023 \mathrm{RD} \\
& \mathrm{N}=683 \quad \mathrm{R}^{2}=0.449 \quad \mathrm{SE}=0.28 \mathrm{~mm}
\end{aligned}
$$

and for aspen

$\mathrm{RINC}=$

$$
\begin{aligned}
& 1.44+0.12 \text { RAC }-0.012 B A-0.34 L^{2}-0.017 Y S C \\
& +0.99 H / A+0.024 A D \\
& N=1141 \quad R^{2}=0.113 \quad S E=0.608 \mathrm{~mm}
\end{aligned}
$$

\section{Stand Growth}

The results of the previous analyses provided information on the magnitude of tree diameter growth response. They also showed how different tree and stand variables influenced respose. An important question at this point was to what degree this improvement in tree growth made up for the lack of stocking on the cut line.

Accurate estimates for a variety of specific stand conditions require a sophisticated stand model that takes into account all relevant variables. Such a model is unavailable. An alternative method was applied that involved selecting typical stand conditions from suitable yield tables and estimating the amount of gain over the area of response. This gain was then compared with the yield lost through line clearing.

Lodgepole pine was selected for the analysis because it showed the most consistent growth response after line clearing and suitable local yield tables are also available for this species. For this comparison, medium high site class and median density were selected from Johnstone's (1976) yield tables. Stand statistics from this class were reasonably close to average conditions of the present sample. Table 3 shows stand statistics for three selected ages. Two extra statistics, $\mathrm{H} / \mathrm{A}$ and $\mathrm{RD}$, were also calculated in order to use the radial increment regressions.

\begin{tabular}{lcccccc}
\hline Table 3. Stand statistics for medium high sites. \\
\hline Stump & $\begin{array}{c}\text { Dominant } \\
\text { height } \\
\text { age }\end{array}$ & $\begin{array}{c}\text { Dominant } \\
\text { H/Age } \\
\text { ratio }\end{array}$ & $\begin{array}{c}\text { BA } \\
\left(\mathbf{m}^{2}\right)\end{array}$ & $\begin{array}{c}\text { Number of } \\
\text { trees/ha }\end{array}$ & $\begin{array}{c}\text { Dbh } \\
(\mathbf{c m})\end{array}$ & RD \\
\hline 20 & 7.6 & 0.38 & 20 & 10185 & 5 & 8.9 \\
40 & 13.4 & 0.325 & 32 & 5030 & 9 & 10.7 \\
60 & 17.4 & 0.29 & 36 & 3180 & 12 & 10.4 \\
\hline
\end{tabular}


With regressions based on the entire data set for pine and the statistics presented in Table 3 as independent variables, annual radial increment values were estimated. Distance variable (LR) was given a value of 0.25 , whch is the median-value between zero and 0.5 for the half of the transect showing growth response, and number of years since cut was 5 . The nominal width of a cut lie is $7.3 \mathrm{~m}$. For this analysis, it is reasonable to consider only one-half of this width, (i.e., $3.65 \mathrm{~m})$, and the length (L) of the adjacent sample transect (which is equal to average dominant height of the sample stand) of 7.6 (Fig. 4), 13.4, and $17.4 \mathrm{~m}$ for the three age classes $(20,40$ and 60 years), respectively. Only half of the cut line width was considered because the other half "belonged" to the adjacent stand on the other side.

Estimated mean annual radial increment values were used to obtain 5-year periodic diameter increments and $A D$ values after 5 years for the three age classes. After reducing tree numbers by $10 \%$ (to approximate mortality trends in the yield tables), new BA values were then estimated for each condition. From these, percentage differences in 5-year BA increments were calculated between the outer half (near the opening) of the transect and the inner half (away from the opening, i.e., control portion). These values were adjusted for differences in transect lengths (L) to account for the actual area of response in relation to the width of cut line (Figure 4).

As shown in Table 4, only about $6 \%$ of the loss is recovered through improved growth in the 20 -year-old stand; in the 40- and 60-year age group the recovered amounts are 6.6 and $6.9 \%$ respectively.

From the above example for lodgepole pine - the species with the greatest and most consistent response - it appears that at best, up to $7 \%$ of growth loss may be recaptured through improved growth of trees adjacent to cut lines. Although the response in 5-year BA increment declined with greater age, older stands with larger trees were able to utilize a greater proportion of the cut line. Thus the loss recovery remained fairly stable at between 6 and $7 \%$. For other species, particularly white spruce, the loss is probably even greater, as indicated by the preceding radial increment analysis. Because of the apparent lack of response in height growth, generally the same may be said about total volume increment.

These differences in BA increment indicate that despite the improved growth along the stand edge, the magnitude of this response falls far short of that required to make up for the loss in growth due to the reduction of stocking on the cut line.

Because the time available (to the end of rotation) to make up for the reduction of stocking on the cut line is shorter, loss in harvest yield will be greater when lines are cleared in older stands. In stands near rotation age, however, salvaging

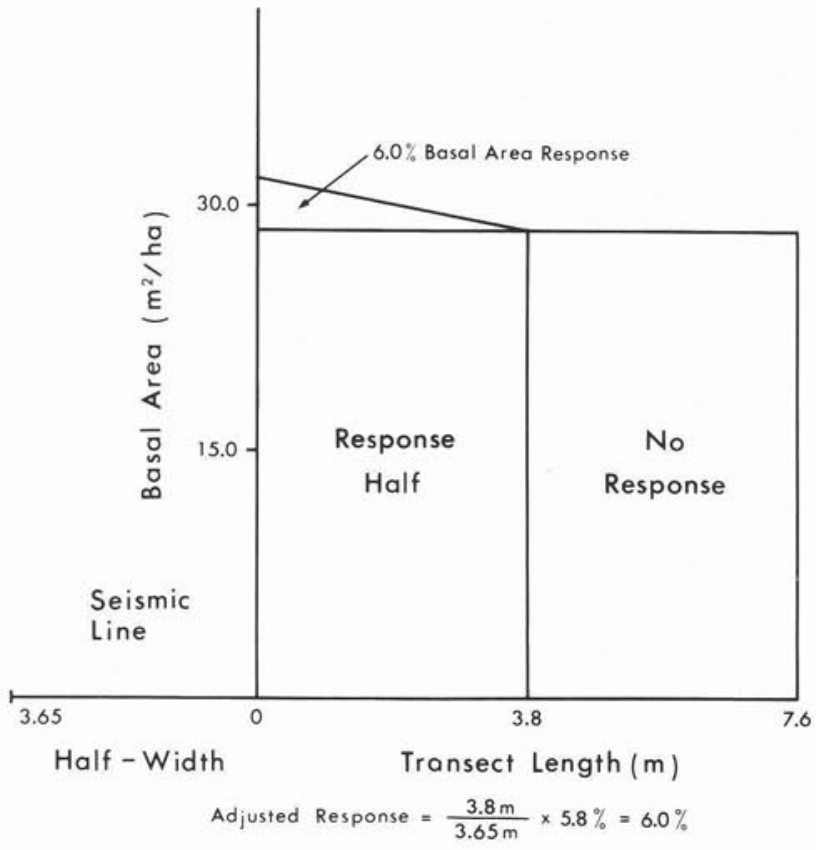

Figure 4. Basal area increment response in relation to seismic line width in 20-year-old lodgepole pine.

timber from cut lines could make up for most, if not all of the potential loss.

In the stand increment example for lodgepole pine, a nominal cut line width of $7.3 \mathrm{~m}$ was used. In contrast, average line width in this study was around $9 \mathrm{~m}$, implying an even greater loss in production than indicated by the above example.

In this study, factors not explicitly considered may have affected growth response after line clearing. Resource companies cutting lines for exploration generally fertilize and reseed - with grasses and clover - disturbed areas to stabilize the site and prevent erosion and for aesthetic reasons. Slope and drainage may also have an effect, especially if the cut line runs along the contour, although the present sampling was concentrated on fairly level terrain and gentle slopes the most common conditions and also most important for wood fibre forestry.

Although variation in these factors may have increased variation in the growth data, thus somewhat reducing the sensitivity of the analysis due to inflated error term, the overall results would not have been affected.

Table 4. Five-year BA increments and percentage differences in increments due to line clearing on medium high lodgepole pine sites at three ages.

\begin{tabular}{|c|c|c|c|c|c|c|c|c|c|c|c|c|}
\hline \multirow{4}{*}{$\begin{array}{l}\text { Stump } \\
\text { age }\end{array}$} & \multirow{4}{*}{$\begin{array}{c}\text { Dom. } \mathrm{H} \\
\text { or } \\
\mathrm{L}(\mathrm{m})\end{array}$} & \multirow{4}{*}{ L/2 } & \multicolumn{3}{|c|}{ Mean Dbh $(\mathrm{cm})$} & \multicolumn{3}{|c|}{ Basal area $\left(m^{2} / h a\right)$} & \multicolumn{2}{|c|}{$\begin{array}{c}\text { Number of } \\
\text { trees/ha }\end{array}$} & \multirow{3}{*}{\multicolumn{2}{|c|}{$\begin{array}{l}\text { Percentage } \\
\text { difference }\end{array}$}} \\
\hline & & & \multirow{3}{*}{$\begin{array}{l}\text { Start of } \\
\text { period }\end{array}$} & \multicolumn{2}{|c|}{ Five years later } & \multirow{3}{*}{$\begin{array}{l}\text { Start of } \\
\text { period }\end{array}$} & \multicolumn{2}{|c|}{ Five years later } & \multirow{3}{*}{$\begin{array}{c}\text { At } \\
\text { start }\end{array}$} & \multirow{3}{*}{$\begin{array}{c}\text { Five } \\
\text { years } \\
\text { later }\end{array}$} & & \\
\hline & & & & $\begin{array}{l}\text { Within } \\
\text { stand }\end{array}$ & Responding & & \multirow{2}{*}{$\begin{array}{l}\text { Within } \\
\text { stand }\end{array}$} & \multirow{2}{*}{$\begin{array}{c}\text { Responding } \\
\text { edge }\end{array}$} & & & & \\
\hline & & & & (control) & edge & & & & & & Actual & Adjusted \\
\hline 20 & 7.6 & 3.8 & 5 & 6.35 & 6.53 & 20 & 28.50 & 30.14 & 10185 & 9000 & 5.8 & 6.0 \\
\hline 40 & 13.4 & 6.7 & 9 & 9.98 & 10.16 & 32 & 35.20 & 36.48 & 5030 & 4500 & 3.6 & 6.6 \\
\hline 60 & 17.4 & 8.7 & 12 & 12.69 & 12.87 & 36 & 36.68 & 37.73 & 3180 & 2900 & 2.9 & 6.9 \\
\hline
\end{tabular}


The chief causal factors of improved tree growth along openings are greater availability of (1) nutrients and moisture, and (2) space and sunshine. With time, the effect of the latter is generally manifested by increases in crown-stem dimension ratios (i.e., crown length over total height, or crown width over diameter). Analysis of the present data, covering a maximum of 25 years after line clearing, has not yet shown a significant change in these ratios.

\section{Summary And Conclusions}

1. Line clearing in forest stands in western Alberta has resulted in a significant and consistent positive growth response in tree radial increment at breast height for the three major coniferous species, lodgepole pine, white spruce, and black spruce. Aspen showed no consistent response.

2. The largest response was in lodgepole pine, where radial increment increased as much as $40 \%$ within a distance of one-half dominant height from stand edge and within 10 years after line clearing but leveled off to about $20 \%$ in the following 10 years. White spruce and black spruce had responses between 15 and $20 \%$.

3. The most important factors affecting tree growth and response to opening were: dominant height over age at the time of the survey, distance from stand edge, age at the time of clearing, and number of years since clearing.

4. The lack of significant growth response in aspen may in part be due to the clonal habit of the species and difficulties in accurate growth determination arising from the presence of false rings.

5. Stand growth - the ultimate criterion in assessing response - was evaluated from BA estimates, which in turn are directly related to volume growth. With radial increment regressions developed for lodgepole pine, together with appropriate yield table statistics, it was found that a maximum of only about $7 \%$ of the growth loss due to line clearing is recaptured through improved tree growth along such openings in medium-density stands on medium high sites.

6. Losses of about the same magnitude as for lodgepole pine may be expected for black spruce; for white spruce the losses would be somewhat greater and for aspen substantially greater.

7. This study conclusively shows that although cutting lines in forest stands stimulates tree growth along such openings, the magnitude of growth response falls far short of the wood lost due to cutting. Salvaging timber from cut lines in older stands however, would greatly help to minimize this loss during the current rotation.

\section{Acknowledgements}

A number of people worked on this cooperative study between the Forest Research Branch and the Alberta Energy and Natural Resources and the Canadian Forestry Service. Special credit is due to Ted Mueller and Albert Dobokay, Forest Research Branch, Alberta Forest Service, who did a major portion of the field sampling and stem analysis. D. Kuhnke, Canadian Forestry Service, conducted the necessary computer processing and statistical analysis and was also involved in report preparation.

\section{References}

Curtis, R.O. 1982. A simple index of stand density for Douglas-fir. For. Sci. 28: 92-94.

Dancik, B.P., D.I. Crossley, J.F. Reynolds and A.D. Crerar. 1979. The environmental effects of forestry operations in Alberta. Environmental Council of Alberta.

Johnstone, W.D. 1976. Variable density yield tables for natural stands of lodgepole pine in Alberta. Fish. Environ. Can., Can. For. Serv., Ottawa, Ont., For. Tech. Rep. 20

Landbeck, H. 1965. Road width and edge effect in Scots pine. (Original in German). Arch. Forstl. 14: 41-59.

Pfister, R.D. 1969. Effect of roads on growth of western white pine plantations in northern Idaho. USDA For. Serv., Intermt. For. Range Exp. Stn. Res. Pap. 65.

$$
\overbrace{\text { TIM MERLIN }}
$$

\section{TIMMERLINN LIMTEE}

PROFESSIONAL AND TECHNICAL SERVICES

IN FORESTRY AND ENVIRONMENTAL SCIENCES

R.R. No. 2, STE. AGATHE DES MONTS, QUE. J8C $2 Z 8$ 